Vidyaratne K.V.R., \& Priyashantha K.G.

Wayamba Journal of Management 12 (2)

\title{
Impact of Institutional Factors on Employee Satisfaction of Management Assistants University of Ruhuna
}

\author{
K.V.R. Vidyaratne ${ }^{1} \&$ K.G. Priyashantha ${ }^{2}$ \\ Faculty of Management and Finance \\ University of Ruhuna \\ rohini@admin.ruh.ac.lk ${ }^{1}$, prigayan@badm.ruh.ac.lk ${ }^{2}$
}

\begin{abstract}
Employee satisfaction is a key element among other physical resources in an organization for achieving its goals and objectives in the competitive environment. Employees' satisfaction is significant since it has been reported that satisfied workers perform well. However, how the management assistants' satisfaction is decided in a university environment has not been studied in the Sri Lankan context. The main objective of this study is to examine the extent to which Management/Supervision, Organizational/Working conditions, Salary, and Training opportunities, impact management assistants' satisfaction. The research design was explanatory quantitative. The population of this study consisted of the total number of Management Assistants in the state higher education sector in Sri Lanka, of which 100 Management Assistants were drawn as the sample. The sample was selected by using a simple random sampling method. The data collection was done through a self-administered questionnaire. Correlation and Regression analysis were used to analyze the data. The study found that there was a positive impact of Training and Physical environment on employee satisfaction. Salary and Management/Supervision were less impact on employee satisfaction compared to the training and physical environment.
\end{abstract}

Keywords-: Employee Satisfaction, Management Assistants, Management, Supervision, Working Conditions, Salary, Training Opportunities. 


\section{INTRODUCTION}

The higher education of a country plays a major role in the transformation of an individual and also in the growth and development of the society and as well economy. With this rapidly changing competitive environment, any organization has a responsibility to satisfy external and internal customers for achieving its success. (Shun-Hsing Chen, 2006). Higher educational institutes need to ensure the satisfaction of internal customers since internal customer satisfaction directly reflects the satisfaction of external customers. (Oshagbemi, 1997). Moreover, every transaction should be profitable for both the organization and the customers since a strong link between employee satisfaction and customer satisfaction has been reported (Mark graham Brown, 2006; Nebekeretal, 2001). Therefore, every organization needs to pay considerable attention to enhancing employees' performance and competencies by identifying the major strengths and weaknesses of the employees.

In any organization, human resources are considered a strategic asset. There is no exemption in the higher educational institutes. In the
Higher Education sector in Sri Lanka, there are two main types of internal customers namely academic employees and nonacademic employees. The university's academic and non-academic staff is being considered as strategic assets of the university. All levels of employees should be worked together to improve the quality and the relevance of the final output, graduates. The quality and the relevance of the output in universities will be socially and economically important since the output is graduates who will be the backbone of a country. Since the quality of output is dependent on the satisfaction of internal customers, as reported in the literature, it is necessary to clarify what factors affect the satisfaction of internal customers.

\subsection{Research Problem}

The managers have placed great importance on the construct of job satisfaction in this changing and competitive higher education market due to job involvement and performance may depend on the satisfaction and motivation of the employee. Many studies have been shown that employee satisfaction is an important factor in relating to positive and negative outcomes (Neff, 2003; Wagner, 2007) in many institutions and many areas. 
In the globe as well as in Sri Lanka, the literature on nonacademic nonadministrative employee satisfaction, especially in Management assistants in the higher education sector, is very low \& limited compare to customer satisfaction, administrative employee satisfaction, or academic employee satisfaction, especially in Sri Lanka. Therefore, employee satisfaction in the Non Academic non-administrative category especially in Management Assistants and allied grades in the Higher Education sector in Sri Lanka is still required study and survey. They are neglecting factors that affect the satisfaction/dissatisfaction of the Management Assistants as nonacademic members, in the state higher education sector in developing countries such as Sri Lanka. This study aims and tries to fill this gap in studying the factors that affect the employee satisfaction of the Management Assistant staff members of the University.

\subsection{The Context}

The University of Ruhuna is a Government University which is a leading national university of Sri Lanka, strives to provide the best learning environment to achieve international standards. The University has always committed to developing a fraternity of competent professionals of international standards and caliber who are innovative, analytical, and independent while reaching its goals through improving the quality and relevance of its educational and research programs. The higher education sector at the global level, as well as Sri Lanka, is changing as a result of globalization and the digital revolution. Moreover, the current COVID pandemic situation has sped up the situation. Thus, the University of Ruhuna was selected as one of the most appropriate contexts to study the factors affecting the satisfaction of management assistants of universities.

\subsection{Literature}

Internal customer satisfaction influences organizational performance (Shun-Hsing, 2006), it relates to positive and negative outcomes (Neff, 2003; Wagner, 2007); negative relationship with negative work outcomes (Wagner, 2007; Chee \& Haddab, 2007) and positive relationship with positive outcomes (Neff, 2003) and it facilitates institutional developments (Dubro-Vski, 2001). Employees are more loyal and productive when they are satisfied (Hunter and Tietyen, 1997) and it led to 
lower absenteeism (Shas, 2007 and Gazioglu \& Tansel, 2006). Having good relationships with colleagues, training and education opportunities, carrier developments or any other benefits may be related to the increase of employee satisfaction (Alam Sageer, Sameena Rafat, Puja Agarwal, 2012). Many of these factors have a tremendous impact on the accomplishment of the aims and objectives of the organization in providing effective services and increasing the effectiveness and efficiency of staff. It would largely depend on their morale and job satisfaction (A1- qallaf, 2006). Organizations should have satisfied and happy staff to achieve their goals (Oshagbemi, 2000). Understanding employee satisfaction is a critical concept (Siu et al; 1997) while job dissatisfaction is led to the high turnover of employees of the organization (Ynn, 2002). It also affects the profitability of organization operations (Riley, 1993) as well as service quality. Employee turnover estimated cost of American industry is over 5 USD trillion annually (Frank, Finuergan \& Taylor, 2004) due to employee dissatisfaction. More satisfied employees' actions improved organization performance (Heskett et al,
1994) and it influences employee productivity (Derek R. All en and Merris Wilbura, 2002). "The success of any organization is directly linked to the satisfaction of the employees" (Freeman, 2005) and unhappy employees fail to participate towards the organizational goals and objectives (Likert, 1961).

There are some management theories and models that satisfy people. As per the scientific approach, planning job, establishing best practices, incentives such as financial, good working condition, and training are factors that helps to satisfy the people. There are two kinds of satisfaction factors called intrinsic and extrinsic, Intrinsic factors mean selfsatisfaction, and extrinsic factors come from outside of the individual such as rewards like money, grades, threats, punishment, etc. The right equipment, people with the right knowledge, skills, abilities, and attitudes financial incentives, right kind of organizational framework, and willingness to do work are the factors that motivate the employee in an organization, and in presentday many organizations set their goals considering their external and internal customer satisfaction (Tahira Nazir, 2013). Based on such theories and models the research 
model of this study was constructed.

The research objectives of this study are of two types. They are the main objective and specific objectives are as follows.

\subsection{Main objective}

To investigate the effect of the factors on employee satisfaction' among Management Assistant employees who work at the University of Ruhuna.

\subsubsection{Specific objectives}

- To examine the effect of University Management/Superv ision (MGT) on employee

satisfaction of nonacademic nonadministrative staff.

- To examine the effect of Organizational/Wor king Conditions (OC) on employee satisfaction of nonacademic nonadministrative staff.

- To examine the effect of Salary (SAL) on employee satisfaction of nonacademic nonadministrative staff.

- To examine Training opportunities (TRO)

$$
\begin{array}{lr}
\text { on employee } \\
\text { satisfaction of } \\
\text { nonacademic non- } \\
\text { administrative staff. }
\end{array}
$$

\subsection{Conceptualization}

"There are many influences on job satisfaction such as pay, supervision, rewards, benefits, nature of job and relationship with co-workers and supervisors" (chen, sparrow, \& cooper, 2016). furthermore, mithcel et al (2001) have stated that job satisfaction is influenced by economic factors, such as pay, benefits, and rewards, as well as structural and procedural factors reflecting autonomy or fairness. khan et al (2012) have pointed the influence of different determinants of job satisfaction. in the literature, various scales have been developed to measure the different dimensions of employee satisfaction (küskü, 2001); general satisfaction, management (administration) satisfaction, work group satisfaction, job satisfaction, salary satisfaction, and physical environment satisfaction.

Employee benefits influence job satisfaction (Williams, 1995). Job satisfaction is significantly influenced by job performance, absenteeism, and turnover (Speotor 1997). Hence employee satisfaction can reduce staff turnover, improve productivity and 
commitment. Isfac Ahmed (2011) examined the relationship between motivation and job satisfaction of the employees in the higher educational institution and he found that there is a positive relationship between motivation and job satisfaction. This finding is supported by the study of Pool (1997). FatmaKusku (2003) emphasizes that there are differences in satisfaction dimensions between the academic and administrative employees in higher education institutions in a developing country. He has considered "colleague relations satisfaction", "colleague competition level satisfaction" "other workgroup satisfaction" "professional satisfaction" "work environment satisfaction" and "salary satisfaction" of academic and administration employees. Further, he explains that studying the satisfaction level of the staff especially in state Universities is of vital importance for the future of a developing country. As his findings, the economic satisfaction level is rather a law in return for the work done. Employees are more productive when they are satisfied with their jobs. $\mathrm{He}$ has found that factors other than the economic role for productivity and efficiency of higher education institutions. FatmaKusku (2003) explores the employee's satisfaction in higher education: 'the case of academic and administrative staff in Turkey', the general results show that there are significant differences between the level of satisfaction of academic and administrative employees. Professional satisfaction is higher than administrative staff. But colleague relation satisfaction, work environment satisfaction are high in the group of administration staff than the academics. But employees who have academic qualifications are more satisfied employees than employees who have less academic qualifications. He illustrates that employees who have job experience, from 510 years have a low level of job satisfaction. According to the FauziahNoordin (2009), the academic staff of the Malaysian university has a moderate level of job satisfaction and current status, marital status, age, and salary are the factors that significantly affect their job satisfaction of them. As per him 'job satisfaction has a significant impact on employee commitment to the organization, job performance, and motivation and high job satisfaction would lead to lower turnover and absenteeism.' George Kafui Agbozo (2017) examined the effect of environment on job 
satisfaction and the impact of physical and mental environment on job satisfaction and mental environment on employee's performance and findings of the study indicated that most of the staff are satisfied with their work environment and the environment has a significant effect on employee's satisfaction. "The findings are emphasizing the need for management to improve the work environment of employees to boost productivity. Human Bilal (2003) investigate the effect of extrinsic job factors on the satisfaction of workers and found a positive relationship between working conditions, rewards and leadership, and administrative support and job satisfaction of workers.

"Supervision is the task of achieving the desired results using intelligent utilization of human talents and utilizing resources in a manner that provides a challenge to human talent" (Terry, 2010). Many researchers (Karatepe, Avci, 2003; Tailor and Bowers, 1972) say that supervisory leadership is positively associated with job satisfaction and "close supervision contributes to a high level of job satisfaction" (Miller, 1996). The proper relationship between supervisor and subordinate helps to satisfy employees
(Dissanayake et al, 2020). "Poor performance management can occur less motivation, turnover, etc." (Dissanayake D.M.G, 2020). Job resources such as social support from colleagues and supervisors, performance, autonomy start a motivational process that leads to work engagement and higher performance (Bakker \& Demerouti, 2007). Employees were least satisfied with their salary and organizational policies and administration such as communication resources and personal policies. This found has agreed with the findings of Watson (2000) that employees were least satisfied with management communication and internal policies. By considering the above prior research and findings, researchers conceptualized the constructs and the hypotheses for this study (The first hypothesis) which can be depicted as follows.

$\begin{array}{ll}\text { H1: } & \text { University } \\ & \text { Management/Supervi } \\ \text { sor is a significant } \\ \text { factor in employee } \\ \text { satisfaction of } \\ \text { nonacademic non- } \\ \text { administrative } \\ \text { employees of the } \\ \text { University } \\ \text { Ruhuna. }\end{array}$

Employees are highly motivated with good working 
conditions such as tools and equipment, working methods, security guards and parking facility, well ventilated with good light fans and air conditioning, neat and clean office place, rest area and washrooms, as they feeling safe and comfortable in the working environment (Chiradeep

Basu Mallick,2020). Physical separation (e.g. separate cubicles) would result in poor interpersonal skills and it may result in a high level of productivity due to less distracted workers (blogpsychology.wordpress.c om). A better work environment can be developed to effectively motivate employees to behave consistently and remain focused on their organizational goals (Amar, 2004). It's very important to recognize the emerging needs of individuals to keep them committed and provide the work environment as necessitated (Ramlall, 2003). Most people enjoy working and strive to work in those organizations that provide a positive work environment where they feel they are making difference (Milory, 2004). In addition, supportive work environments provide conditions that enable health workers to perform effectively, making the best use of their knowledge, skills, and competencies, and available resources to provide high-quality

outcomes

(Leshabari et al, 2008). Some researchers (Scott, 2000; Strong et al., 1999) have examined the effect of physical work environment on workers' job satisfaction, performance, and health. Researches on quality of work-life have also established the importance of safe and healthy working conditions in determining employees $^{\text {ee }}$ job performance (Franco et al., 2000). A good working environment helps to get quality service and a high level of employee performance (Zhang, 2016). "Work environment has a strong positive relationship with job performance" (Munisamy, 2013). Uncomfortable working environment decrees employee performance and job performance. Alam Sagee et al: 2012). Dennis (1998) and Hullin a smith (1965) prove that employees who are around the age of 50 years were most satisfied with their jobs due to high adaption of the working conditions, organizational policies, and work relationship with peers, students, and supervisors in serving many years of service in the same organization. By considering the above prior research and findings, researchers conceptualized the constructs and the hypotheses (The second hypothesis) for this study 
which can be depicted as follows.

H2: Organizational working condition is a significant factor in employee satisfaction of nonacademic nonadministrative employees of the University of Ruhuna.

Compensation is output and the benefit that employees receive in the form of pay, wages, and also same rewards like the monetary exchange for the employee's performance and satisfaction (Holt, 1993). It is one of the major attracts for employee satisfaction and motivate employee to increase their performance (Ivanceikh \& Glueck, 1989). Compensation means all remunerations received by workers or arise from their job (Gary 2003). Salary has a positive effect on employee performance (Niode \& Umar, 2011), but Subekti \& Setyadi (2016) argued that financial compensation only has an effect on job satisfaction and does not have an effect on job motivation and employee performance. Subekti \& Setyadi (2016) explained that financial compensation accepted by an employee is only limited to reaching job satisfaction. Salary and incentives are two special factors that are usually the most recognized factors to motivate employees in Sri Lanka (Upekha, Seedevi, Aruna, \& Kasun, 2010). Non profit organizations are unable to compare with forprofit organizations in providing pay and incentives (Brandel, 2001). Policies of compensation and benefits such as wages and salary and rewards and penalties are the most important variables for employee satisfaction (AlamSagee et al, 2012). Niederman and Sumner (2004) examine the relationship among key variables of tasks performed salary, job satisfaction and external influences or shocks of the MIS professionals and results show that there are significant changes in tasks, salary and job satisfaction between former and current jobs of the employee. Maria de Lourdes Machado(2011) shows in her study on 'A look to academics job satisfaction and motivation in Portuguese Higher Education Institutions', that employee satisfaction and motivation have a very high positive impact on general satisfaction, and the correlation between them is very high. Aspasia Togia And Athanasios Koustelios (2004) investigated job satisfaction among academic librarians in Greek using six instruments "working conditions" "pay" "promotions" "job itself" "supervision" and 
"organization as a whole" to assess employee satisfaction inventory (ESI). They found that academic librarians of Greek have satisfied with "job itself" "supervision" and less satisfied with "pay" and "promotion". TahiraNazir (2013) designed eight scales in the UK to measure the university teachers' job satisfaction; administration and management, research, supervision, present pay, promotions, physical conditions and behavior of workers ( 'Impact of rewards and compensation on job satisfaction: public and private universities of $U K, 2013^{\prime}$ ) and found that those factors have contributed to enhancing the teacher job satisfaction. As per his study level of job satisfaction in the UK shows that employees perform their job with full freedom and devotion. By considering the above prior research and findings, researchers conceptualized the constructs, and the hypotheses for this study which can be depicted as follows (The third hypothesis).

H3: Salary is a significant factor in employee satisfaction of nonacademic nonadministrative employees of the University of Ruhuna.
Training is a highly useful tool that can bring an employee into a position where they can do their job correctly, effectively, and conscientiously. Training and development have an impact on the performance of employees in their jobs (Nasszai, 2013). Training is essential to any organization in an economical aspect. Positive impact of training to face the today worldwide technology, any organization need to focus on merging training program on updated technology to achieve high employee performance. Positive supervisory, providing a proper work environment, peer support help to archive a success training (Dissanayaka et al, 2020). Promotion and career development such as training programs, the opportunity for promotion, and the opportunity for use skills and abilities can determine the degree of satisfaction of employees. It delivers more pay responsibility, authority, independence, and status (AlamSagee et. al; 2012). Faris Ibrahim Algaribeh (2014) shows that there is a positive relationship between training and employee satisfaction and the quality of the training is the highest contributor to employee performance. Micheal Muma (2014) recommends that formulate the training policies for every employee in all 
sections of the university (Jomo Kenyatta University of Agriculture and Technology) should be regular because it is indicated that training significantly affects their job. Maaly Mefleh Mohammed Ai-Mzary (2015) examine the impact of training on employee job performance and results indicated there is a relationship between effective training and employee's job performance. By considering the above prior research and findings, researchers conceptualized the constructs and the hypotheses (The fourth hypothesis) for this study which can be depicted as follows.

H4: $\quad$ Training opportunities are a significant factor in employee satisfaction of nonacademic nonadministrative employees of the University of Ruhuna.

"Work engagement leads to the development of an organization as a growth of revenues net income and employment" (Gorgievski and Morino, 2014). The current global trend of the employee market is a low level of work engagement and it leads to investment in human resource strategies and investment in human resources to adjust to the problem. The lower level of performance led to lower productivity and high cost for the organization (Dissanayake and Sujeewa, 2020). According to Sanyal and Hisam (2015), there was a huge problem with the performance of the educational sector employees, and the hotel industry in Pakistan is facing the same problem (Ameeq and Hanif, 2003). Commitment and satisfaction are positively related to each other (Wlliam Brown et al, 2003).

Conceptualization

framework, figure 1.1 which is based for this study is divided into dependent and independent; the dependent variable is employee satisfaction and the independent variables are institutional factors; University management, Organizational/Working conditions, Salary, and Training opportunities.

\section{METHODS}

The research design adopted is descriptive, and is quantitative. This design was adopted since the literature suggests that this type of research design is ideal for testing objective theories by examining the relationship among variables (Crewel, 2013). The population of this study is Management Assistants and allied grade employees who represent the 


\begin{abstract}
nonacademic nonadministrative employees in the state higher education system in Sri Lanka. The sample size was 100 Management Assistants employees of the University of Ruhuna. The sample was drawn based on the rule of thumb introduced by Sekaran (2003), which is ten times the number of total items used to measure the concepts used in the study. Due to the time constraints, the researchers limited the sample size to 100 , which is $50 \%$ of the real sample size according to Sekaran's (2003) rule of thumb. The details of the sample size, and how it was drawn according to the rule of thumb of Sekaran (2003) are depicted in the following table 1.
\end{abstract}

Both primary and secondary data were collected for the study. Primary data was collected through a selfadministered questionnaire, which consisted of six parts. Part one consisted of demographic variables which were considered in this study as control variables. Five demographic variables were used in this regard. Part two, three, four, and five consisted of statements to measure the independent variables; University management, Organizational/Working conditions, Salary, and Training opportunities.
Part six consisted of statements to measure the dependent variable; Employee satisfaction. Primary data was used to analyze the results and test the conceptual framework developed for this study. The Secondary data was collected using annual reports of the university, previous other records, a literature review by referring to textbooks articles, websites, and research papers produced by various researchers over the year.

This information was used to define the problem and develop the conceptual framework. The primary data analysis was done using SPSS. The data were analyzed using descriptive statistics, reliability, correlation, and regression. The correlation was used to identify the forms of relationships among the variables and simple Lenoir Regression was used to test the statistical significance of the hypothesis and to measure the strength of the impact of independent and dependent variables.

\section{DATA ANALYSIS AND DISCUSSION}

In this research, the response rate from the sample drawn was $100 \%$. Out of 100 Management Assistants, the 
majority of respondents belong to the age category 47 53 , representing $23 \%$ of the sample while the age category of 26-32 and 33-39 represent the same percentage of $19 \%$ and age category of 18-25 represent only $9 \%$. It indicates that most Management assistant employees are between the age group 26-39 which represents $38 \%$.

Out of the 100 respondents, females are represented $71 \%$ while males are represented $29 \%$ of the sample. It indicates that most of the Management Assistants are female. The majority of respondents of the sample were married, who represent $81 \%$ and only $19 \%$ of them were unmarried. Out of the 100 respondents, 39\% have more than fifteen years of experience in the institute, and $32 \%$ of the sample have $1-5$ years of experience. The lowest percentage of $13 \%$ employees were with 11-15 years service experience. All the staff has at least GCE (O/L) qualification. Most of the employees have GCE (A/L) qualifications (36\%) and only one employee has achieved professional qualifications. Employees who have a postgraduate degree or university diploma are $7 \%$ and $6 \%$ respectively.

\subsection{Reliability of study variables}

Reliability of measures is an indication of the stability and consistency with which the instrument measures the concept, and helps assess the "goodness" of a measure (Sekaran, 2003). Sekaran (2010) used a rule of thumb to assess Cronbach's alpha value, where if it is less than 0.60 , it is considered poor reliability when it is between 0.60 and 0.70 , it is considered fair reliability, and if it is in the range of 0.70 to 0.80 , it is considered good reliability. Moreover, if the same value is more than 0.80 , it is treated as very good reliability (Ibid). As per the results of the study, the Cronbach's alpha values reported are depicted in the table 2, and it is evident that the reported values have very good reliability, representing the higher internal consistency of measures used to measure the research variables.

\subsubsection{Correlation coefficients of study variables}

The Correlation coefficients measure the strengths of the relationship between two variables (Nickolas, 2017). The Correlation coefficients indicate the direction of the relationship, while the amount 
of the correlation indicates the strengths of the relationship (Rajasekar, 2013).

\subsubsection{Correlation coefficients with a control effect}

Table 3 displays the correlation between study variables with relationships of controlling variables. It is reported that there are positive relationships between independent variables (SAL, $\mathrm{r}=.384, \mathrm{p}<0.01),(\mathrm{TRO}, \mathrm{r}=.069$ $\mathrm{p}<0.01),(\mathrm{MGT}, \quad \mathrm{r}=.330$ $\mathrm{p}<0.01$ ), and (PE, $\mathrm{r}=.503$ $\mathrm{p}<0.01)$, and dependent variable. When it comes to demographic variables, it is evident that all the demographic (control) variables have significant relationships (age- $\mathrm{r}=.320$, $\mathrm{p}<0.01$, gender $-\mathrm{r}=.133, \mathrm{p}<$ 0.01 , marital status $-r=-.144$, $\mathrm{p}<0.01$, service period $-\mathrm{r}=$ $.063, \mathrm{p}<0.01$ and education $\mathrm{r}=-.029, \mathrm{p}<0.01)$ with employee satisfaction.

\subsection{Regression coefficients of study variables}

Regression analysis is used in a situation where one independent variable is hypothesized to affect one dependent variable (Sekaran \& Bougie, 2016). Table 4 depicts the Lenoir regression coefficients of the study variables. It is reported that the $\beta$ coefficient of study variables is significant proving that set hypothesis can be accepted.

According to table 5, R-value is 0.591 . It means that there is a high relationship between the dependent variable (employee satisfaction) and independent variables (University management,Organizational/ Working conditions, Salary, and Training opportunities.) of the study. In other words, University management,Organizational/ Working conditions, Salary, and Training opportunities are increased by one unit each simultaneously, level of employee satisfaction is increased by $35 \%$. The $\mathrm{F}$ value (mathematical accuracy) has been significant $(\mathrm{F}=0.000)$. $\mathrm{R}$ square value (R2) means the predictive fit capacity or accuracy of the model. It shows $0.349 \mathrm{R}$ square value $(\mathrm{R} 2=0.349)$. Using adjusted $\mathrm{R}$ square, it can be described the independent variables by the dependent variable. Table 6 implies that $32 \%$ of the dependent variable is described by independent variables. Mathematical accuracy has been significant ( significance $=0.000$ ) as per table 6. Finally, it can be concluded the model is accurate.

a. Predators: (constant), University management, 
Organizational/Work ing conditions,

Salary, and Training opportunities.

b. Dependent variable:

Employee

Satisfaction

\section{DISCUSSION}

This research study attempted to measure the impact of institutional factors; 1. University management, 2 . Organizational/Working conditions, 3. Salary and 4. Training opportunities on employee satisfaction with special reference to the University of Ruhuna in Sri Lanka. According to the results of the data analysis, two hypotheses can be accepted while the other two hypotheses were rejected. Organizational /working conditions and Training show a very important role in employee satisfaction. There is a minor effect of Management/ Supervisory and Salary on employee satisfaction.

There is a positive relationship between organizational/working conditions and employee satisfaction as per the researcher's findings. According to the theory of Maslow's hierarchy of needs, and Herzberg's two-factor theory, it is positively accepted with the results of this study findings. Previous researchers (FatmaKusku, 2003; Anthonia, 2011; Alam, Sameena \& Puja, 2012; Benon \& Epiphany, 2014) also mentioned there was a strong impact between these two variables. The results of Muhammad, Rizwan, \& Yasin (2012) show that the work environment influences job satisfaction. Many studies show that employee satisfaction is increased with the job-related conditions and work environment (Becker and Billings, 1993; Riggs and Knight, 1994).

Findings confirm the prior research studies such as employees tend to satisfy with their job when they have effective training as ongoing learning for them in the workplace (Abdul, Ahmad, and Amran, 2012)". Angela (2014), Maaly Meflesh Mohammed Ai-Mzary (2015), and (Mohammd, 2014) stated that training affects the performance of the employee. Boateng (2011) stated that training is a significant impact on employee productivity.

It is argued (Srivastva, 1975) that job satisfaction has no direct correlation to the supervisor-employee relationship, which is supported by the study of Kakyom \& Giri (2010). Employee satisfaction is not wholly determined by the 
employee-supervisory

relationship but by other factors (Srivastva, 1975).

Findings confirm that prior research studies such as "Pay" is not the main influence on job satisfaction and motivation (Evans, 1999; Saleem, 2009; Maria de Lourdes Machado, 2011)", "Research contradicts the assumption that job satisfaction and motivation depends on pay," si; this is not the main influence on job satisfaction (Evans, 1999; Saleem, 2009). This was proved on findings of Mari, Rui, Jose \& Odilia (2011). Most studies show the negative relationship between turnover and satisfaction with pay (Bretz, Boudrcaur, and Judge, 1994; Werbel and Gilliland, 1999). Employee dissatisfaction happens when the desired pay is higher than the existing pay and pay satisfaction occurs when employees are adopted or correspond to existing pay or greater than desired pay ( Niederman and Sumner,2004). Pay is not the main influence on job satisfaction and motivation (Evans, 1999; Saleem, 2009; Maria de Lourdes Machado, 2011). Aspasia Togia and Athanasios Koustelios (2004) found that academic librarians of Greek have satisfied with "job itself", "Supervision", and less satisfied with "Pay" and "Promotion".

\section{CONCLUSION}

Management/Supervisory and salary are less impact on Employee Satisfaction as per the findings of this research. It can be concluded that rewarding employees in training opportunities and physical environment is a significant impact on employee satisfaction and that would, in turn, increase their performance of them, and the mental health of employees is a significant cost burden in the workplace. The results of this research help the management to reach a higher level of employee satisfaction through identification of the causes of employee satisfaction because training opportunities and physical environment have a significant impact on employee satisfaction according to the research results. Thus the management of the relevant organization can use our measures to diagnose and improve employee satisfaction with various aspects to maximize employee satisfaction and to the achievement of organizational goals and objectives.

Employees are the root cause of the quality and success of the institution, so this study has implications for the management of higher education institutes, and policymakers to identify the problems and to be designed 
Vidyaratne K.V.R., \& Priyashantha K.G.

Wayamba Journal of Management 12 (2)

\begin{abstract}
management strategies to
increase efficiency and

effectiveness in the university system. The research has utilized a quantitative approach for the study. Therefore, the present study cannot be generalized to all other higher education sectors. The responses expressed are on the Likert scale and conclusions are made through the statistical analysis, which does not support human feelings, sentiments, or aspirations. Therefore, a thorough qualitative, longitudinal study and rich interview could have impacted to draw a different conclusion. Further research can be conducted by including more universities from overall Sri Lanka and by broadening the sample size.
\end{abstract}




\section{APPENDIX}

Independent variables

Dependent variable

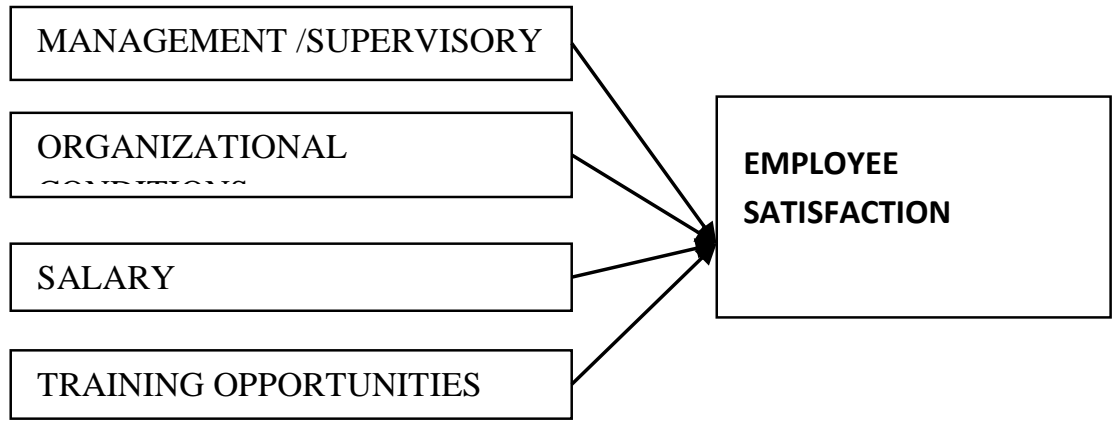

Figure 1: Conceptual framework

Source: Author's construct, 2020

Table 1: Sample of the study

\begin{tabular}{|l|c|c|c|}
\hline Variable & $\begin{array}{l}\text { Number of } \\
\text { statements to } \\
\text { measure } \\
\text { variables }\end{array}$ & Multiplier & Total \\
\hline Demographic & 5 & 10 & 50 \\
\hline Salary (SAL) & 3 & 10 & 30 \\
\hline Training opportunity (TRO) & 3 & 10 & 30 \\
\hline Management (MGT) & 3 & 10 & 30 \\
\hline Physical Environment (PE) & 3 & 10 & 30 \\
\hline Employee satisfaction (ES) & 3 & 10 & 30 \\
\hline $\begin{array}{l}\text { Sample size according to } \\
\text { Sekaran }\end{array}$ & & & 200 \\
\hline Decided sample size & & & 100 \\
\hline
\end{tabular}

Source: Author's construct, 2020 
Vidyaratne K.V.R., \& Priyashantha K.G.

Wayamba Journal of Management 12 (2)

Table 2: Reliability statistics of the study variables

\begin{tabular}{|l|c|c|}
\hline Variables & $\begin{array}{l}\text { Cronbach's } \\
\text { Alpha value }\end{array}$ & No. of items \\
\hline Salary ( SAL) & 0.895 & 3 \\
\hline Training opportunities (TRO) & 0.840 & 3 \\
\hline Management/Supervisory (MGT) & 0.749 & 3 \\
\hline Physical environment (PE) & 0.835 & 3 \\
\hline Employee satisfaction (ES) & 0.835 & 3 \\
\hline
\end{tabular}

Source: Survey data (2020)

Table 3: Correlation coefficient with control effect.

\begin{tabular}{|c|c|c|c|c|c|c|c|c|c|c|}
\hline & $\begin{array}{l}20 \\
\frac{5}{60} \\
\sum \\
2\end{array}$ & $\begin{array}{l}\sum_{20} \\
0_{00} \\
\sum\end{array}$ & $\begin{array}{l}0 \\
\frac{\pi}{4} \\
20 \\
2\end{array}$ & 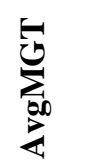 & $\frac{151}{200}$ & $\underset{4}{\infty}$ & ن⿺辶ِّ & 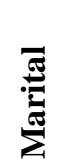 & : & : \\
\hline AvgES & 1 & & & & & & & & & \\
\hline AvgSAL & $\begin{array}{r}* * \\
.384\end{array}$ & 1 & & & & & & & & \\
\hline AvgTRO & $\begin{array}{c}* \\
.069 \\
\end{array}$ & $\begin{array}{c}* * \\
.239 \\
\end{array}$ & 1 & & & & & & & \\
\hline AvgMGT & $\begin{array}{c}* * \\
.330 \\
\end{array}$ & $\begin{array}{r}* * \\
.473 \\
\end{array}$ & .198 & 1 & & & & & & \\
\hline AvgPE & $\begin{array}{c}* * \\
.503 \\
\end{array}$ & $\begin{array}{c}* * \\
.553 \\
\end{array}$ & $\begin{array}{c}* * \\
.375 \\
\end{array}$ & $\begin{array}{c}* * \\
.591\end{array}$ & 1 & & & & & \\
\hline Age & .320 & .026 & .039 & -.158 & -027 & 1 & & & & \\
\hline Gender & .133 & .162 & -.026 & .124 & .051 & -.102 & 1 & & & \\
\hline Marital & -144 & -.058 & .011 & .132 & .006 & $\begin{array}{c}* * \\
-.583\end{array}$ & $\begin{array}{l}* * \\
.25 \\
3 \\
\end{array}$ & 1 & & \\
\hline $\begin{array}{l}\text { Service } \\
\text { period }\end{array}$ & -063 & -.073 & -.055 & $\begin{array}{c}* * \\
-.243\end{array}$ & -136 & $\begin{array}{c}* * \\
.808\end{array}$ & $\begin{array}{l}- \\
118\end{array}$ & - & 1 & \\
\hline Education & -029 & -.029 & -.050 & .024 & -004 & -.166 & $\begin{array}{l}.15 \\
7\end{array}$ & $\begin{array}{l}.21 \\
8\end{array}$ & $\begin{array}{l}- \\
203\end{array}$ & 1 \\
\hline
\end{tabular}

Source: Survey data (2020) 
Table 4: Lenoir regression coefficients of the study variables

\begin{tabular}{|l|l|l|}
\hline Model & B & Significant \\
\hline Constant & 2.790 & 0.000 \\
\hline AvgSAL & 0.134 & 0.105 \\
\hline AvgTRO & 0.245 & 0.001 \\
\hline AvgMGT & 0.002 & 0.984 \\
\hline AvgPE & 0.396 & 0.000 \\
\hline
\end{tabular}

Source: Survey data (2020)

Table 5: Model summary for the regression analysis

\begin{tabular}{|l|l|l|l|l|l|}
\hline $\mathbf{R}$ & $\mathbf{R}^{\mathbf{2}}$ & $\begin{array}{l}\text { Adjusted } \\
\mathbf{R}^{\mathbf{2}}\end{array}$ & $\begin{array}{l}\text { Standard } \\
\text { error of } \\
\text { the } \\
\text { estimate }\end{array}$ & F change & Sig F \\
\hline $0.591^{\mathrm{a}}$ & 0.349 & 0.322 & 0.62726 & 12.749 & $0.000^{\mathrm{b}}$ \\
\hline
\end{tabular}

Source: Survey data (2020) 


\section{REFERENCES}

Abdul Hakim Ahmad Dardar, Ahmad Jusoh and Amran Rasli, (2012). The Impact of Job Training, job satisfaction and Alternative Job Opportunities on Job Turnover in Libyan Oil Companies.

Adenika,

A. (2011). Organizational climates as a predictor of employee job satisfaction: evidence from covenant University.

Alam Sageer, Sameena Rafat, Puja Agarwal, (2012). Identification of variables affecting employee satisfaction and their impact on the organization, PP 32-39.

Aspasia Togia, (2004). Job satisfaction among Greek academic librarians.

Ayman, R. \& Chemers, M.M (1983). Relationship of supervisory behavior rating to work group effectiveness and subordinate satisfaction among Iranian managers.
Becker, A.B, (2009). Building engagement in the work place.

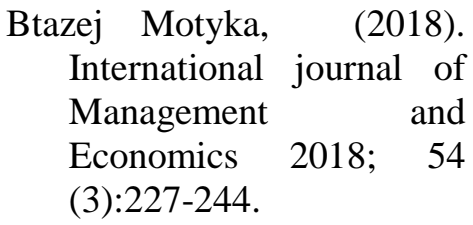

Chih-Chieh Wang, HuiH.H., Yau-De Wng, (2019). Abusive supervision and employee engagement and satisfaction: the mediating role of employee silence

Chiradeep Basu

Mallick, (2020). What is job satisfaction? Definition, factors, Importance, statistics and examples.

Dissanayak G.M.D.C. and Sajeewa W.W.A.N, (2020). Impact of training on non-managerial employee performance in star rated hotel industry in Matale district.

Edward W. Miles, Sreven L. Patric, Wesley C. King Jr, (1995). Job level as a systematic variable in predicting the relationship between supervisory communication and job satisfaction.

\section{Expert programme \\ Management, copy wright, (2009-2018).}


Faris, I.A. (2014). The relationship between training and employee performance: A case study of Jordanian public Universities, Journal of advanced social research Vol. 4, No. 12, December 2014, 01-15.

FatmaKusku, (2003).

Employee satisfaction in higher education: the case study of academic and administrative staff in Turkey.

FatmaKusku, (2001).

Dimensions of employee satisfaction: A state university example, METU studies in Development, 28 (3-4), 2001, 399-430.

FatmaKusku, (2001).

Dimension of employee satisfaction: a state university example.

Fauziah Noordin, (2009). Vol.5, Levels of job satisfaction among Malaysian Academic staff.

George F. Dreher, (1981). Predicting the salary satisfaction of exempt employees.

George Kafui Agbozo, (2017). The effect of work Environment on job satisfaction: Evidence from the Banking sector in Ghana, Volume 5, Issue 1, February 2017, pages: $12-18$.

Greta Marie Giese, (2018). Hertzberg's Theory of motivation as a predictor of job satisfaction: A study of Non

Academic community colleague employees.

Greta Marie, (2018). Herzberg's theory of motivation as a predictor of job satisfaction: A study of nonacademic community college employees.

Huma Bilal, (2003). Job satisfaction of University teachers: Impact of working conditions and compensation, Rev. Integr.Bus.Econ.Res.Vol. 1 (1).

Hun-Wen Lee \& MeiChun Lin, (2014). A study of salary satisfaction and job enthusiasm-mediating effects of psychological contract.

Ishfaq Ahmed, (2010). Effects of Motivational Factors on Employees Job Satisfaction a Case study of University of the Punjab, Pakistan. International journal of Business and 


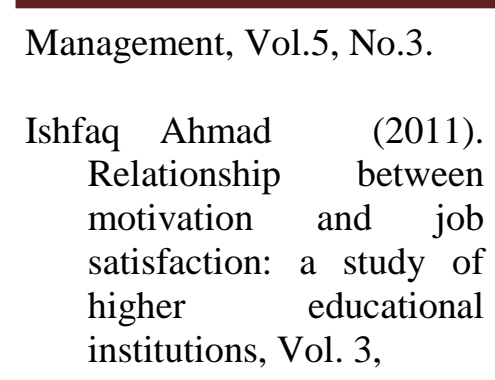

Kakyom Kim \&Giri Jogaratnam, (2010). Effects of individual actors on job satisfaction and intent to stay I in the hotel and restaurant industry.

Maaly Mefleh Mohammed Al-Mzary, (2015). Training and its impact on the performance of employees at Jordanian Universities from the perspective of employees: The case of Yarmouk University, Vol. 6, No. 32, 2015
Maria de Lourdes Machado, (2011). A look to academics job satisfaction and motivation in Portuguese higher education institutions.

Melanie K. Jones, Richard J. Jones, Paul L. Latreille \& Peter J. Sloane (2008). Training, Job Satisfaction and Workplace Performance in Britain: Evidence from WERS 2004.
Michael

Muma, (2014). Effect on training needs assessment on employee commitment in public universities: A case study of Jomo Kenyatta University of Agriculture and technology, Vol.4.

Mohamad Nossam, (2010). The relationship between employee perceptions of equity and job satisfaction in the Egyptian private universities.

Muhmad, Rizwan, \& Yasin, (2012). The impact of pay and promotion on job satisfaction: Evidence from higher education institutes of Pakistan.

Muhammad, Kamal, Paria, Ramsha, Noor, Rukia, \& Syad,(2018). Is supervisor support matter in job satisfaction? A moderating role of fairness perception among nurses in Pakistan.

Muhammad, \& kamal, (2017). Impact of supervisory support on job satisfaction.

Paul E. Spector, (1985). Measurement of human service staff satisfaction: Development of the job satisfaction survey, (vol. 13). 
Ping He, Hank Findley \& Robert Wheatley, (2014). The effects of training on job satisfaction and service quality among temporary employees: the mediating role of affective commitment.

Peiris, and Weerakkody, (2012). Determinants of Employee Absenteeism in Electrical Industry in Sri Lanka.

Ralph Schroder, (2008). Job Satisfaction of Employees at a Chritian University, Journal of Research on Chritian Education, Vol.17, 2008 issue 2.

Reehad, S. Michel R., Bashshur, Marcus (2011). Employee satisfaction with management above the level of immediate supervision.

schachter's theory of emotion, wickpedia, (2019).

Sharon Ruvimbo Terera, (2014). The impact of rewards on job satisfaction an employee retention.

Shun- Hsingchen, (2006). Vol.18, The dependent of an employee satisfaction model for Higher Education.
Stewan W. Schmidt. The relationship between satisfaction with workplace training and overall job satisfaction.

Susan Horton, (2007). High Aspirations: Differences in employee satisfaction between University faculty and staff.

TahiraNazir, (2013).

Impact of rewards and compensation on job satisfaction: Public and private Universities of UK, Middle- East Journal of scientific research 14(3):394-403, 2013

TahiraNazir, (2013).

Impact of rewards and compensation on job satisfaction: public and private universities of UK.

Theresa M Welbourne, Stevan B. Andrews and Alice O. Andrews, (2005). Back to basics: learning about employee energy and motivation from running on my treadmill.

Theresia, L. and Bangun, R. (2017). Service quality that improves customer satisfaction in a University: a case study in 
Vidyaratne K.V.R., \& Priyashantha K.G.

Wayamba Journal of Management 12 (2)

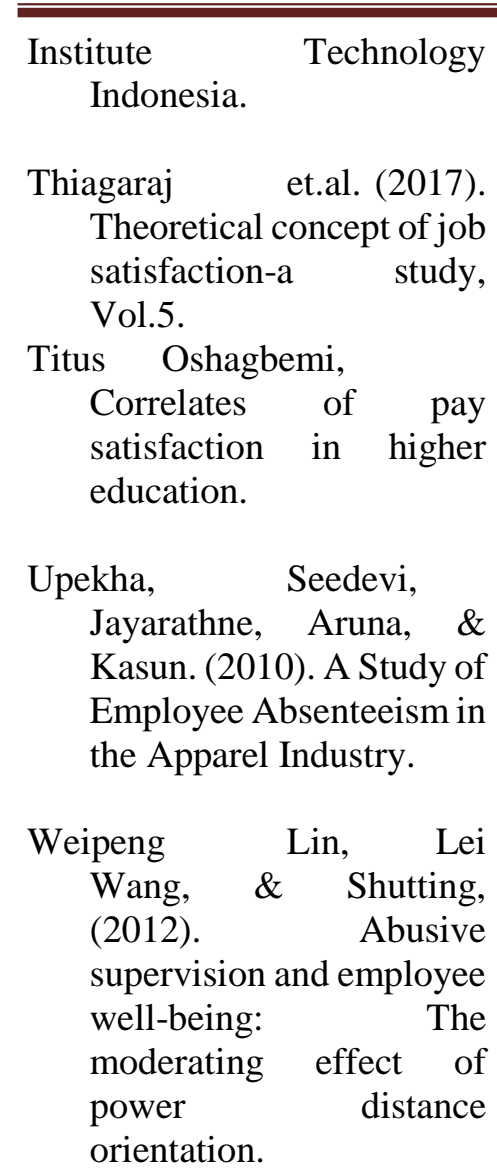

from the German

labor market. 